\title{
Mediating Effect of Work-Life Balance between Motivation and Job Satisfaction and Its Impact on Emotional Intelligence of Mystery Shopping Professionals
}

\author{
Dr. Anand Shankar Raja \\ Manivannan $^{1}$
}

\begin{abstract}
Article Summary
Received 2019-05-08

Accepted 2019-05-29

Published 2019-06-01

Keywords

Mystery shopping

Job Satisfaction

Motivation

Work-life balance

Emotional Intelligence
\end{abstract}

How to cite?

Manivannan, A. S. R. (2019). Mediating Effect of Work-Life Balance between Motivation and Job Satisfaction and Its Impact on Emotional Intelligence of Mystery Shopping Professionals. SEISENSE Journal of Management, 2(4), 14-34.

doi:10.33215/sjom.v2i4.160

Copyright (C) 2019 The Author(s)

\section{(cc) BY}

\author{
CHRIST (Deemed to be University), Bangalore, \\ Karnataka - India
}

\begin{abstract}
Purpose- Enhancing job satisfaction through motivation and Work-Life Balance (WLB) and checking the overall impact on Emotional Intelligence of mystery shopping professionals is the aim of this research. The work depends on factors such as sudden demand, high workload, on-time submission of assignments, a new area for exploration and fluctuation in pay scale.

Design- The data were collected from mystery shopping professionals through social media platform using a questionnaire link $(\mathrm{N}=338)$. The sampling technique employed in this study was a convenient sampling technique. CFA (Confirmatory Factor Analysis) using AMOS software was performed. The questionnaire instrument SSREI, GJSS, WEIMS and (Tasdelen's WLB) were adopted for this study.

Findings- The study revealed that motivation has a positive impact on Work-life balance and intern enhances the job satisfaction of mystery shoppers. However, the overall impact on EI is negative. The Goodness of Fit Index such as (AGFI, NFI, TLI, CFI, RMSEA, RMR, and AVE) indicates a good fit of the Structural Equation Model.

Originality/Value: The study reflected on the four essential concepts, which has evolved in the domain of HRM and OB for many years. In the context of mystery-shopping professional, it has been used and the recommendations will help the market research agencies and the mystery shoppers. Exploring Work-Life Balance (WLB) as a mediating variable between motivation and Job satisfaction and the overall impact on EI of mystery shopping professionals is a new insight.
\end{abstract}

\footnotetext{
${ }^{1}$ Corresponding authors email address: anand.shankar@christuniversity.in
} 


\section{Introduction}

Over work is a problem, claims (Ruth Eikhof, 2007) and Work-Life Balance (WLB) is the fundamental property and key instrument, which enhances "Life satisfaction". Thus, using WLB, as a mediating variable is new when compared with other research study conducted on mystery shoppers. This study is about the most essential elements needed for a mystery-shopping professional to succeed in life and career. Thus, importance motivation, work-Life Balance (WLB), job satisfaction and Emotional Intelligence are the major focus. Balancing personal life and career life is important for any working professional. This study will be a revelation to all the market research firms to design flexible and standard work description for mystery shopping professionals. This research will also give them a spark to provide sufficient training and development program for developing the "Ghost Shopping" professionals for a successful career. Mystery shoppers should understood the nature of mystery shopping job and its functioning because it is a unique profession, which is not like other marketing research job. Furthermore, if mystery shoppers take initiative to self-motivate themselves they will improve on their emotional skills. Significantly, a lot of scope is available for future researchers to explore more about mystery shoppers. (Adil \& Ab Hamid, 2019), points out that the managers should use motivation as a tool to motivate and extract more work from employees. However, in case of mystery shoppers this is not possible, as they do not share relationship and communication. Thus, the title of the study is a perfect blend of all the important variables.

\section{Research Questions}

- Does motivation influence job satisfaction of mystery shoppers and enhance Emotional Intelligence (EI)?

- Can Work-Life Balance (WLB) enhance better Job satisfaction and regulate the Emotional Intelligence (EI)?

- Is there a logical relationship between Motivation, Work-life Balance, Job satisfaction and Emotional Intelligence (EI) among ghost shoppers?

\section{Literature Review}

In the past decade, Work-life Balance (WLB) was a major concern (Crompton \& Lyonette, 2006; Keeton, Fenner, Johnson, \& Hayward, 2007). Work and family balance is the hottest topic for discussion, which is popular in the debate platform. Professionals work hard and get less reward especially the women professionals who take a great responsibility to balance work and family (Albertsen, Rafnsdóttir, Grimsmo, Tómasson, \& Kauppinen, 2008). Indeed WLB has become a subjective matter even for part-time professionals and freelancers. Changes in the job market have brought in new stress and pressure even for part-time professionals causing problems related to emotions, motivations and job satisfaction. Stress due to less job satisfaction and imbalance between job and family leads to burnout and reduces the efficiency says (Angerer, 2003; Maslach, Schaufeli, \& Leiter, 2001). Vischer (2007) says that stress leads to damage in physical health (Goldstein \& Kopin, 2007; Meadows, 2017; Sliter \& Yuan, 2015).

For freelance professionals, job task depends on the sudden demand in the market and has no fixed time and routine schedule. Thus, a "time blind" occurs causing a serious problem between work and family. The institutions providing jobs for freelancers are not worried about the feelings of the professionals but are keen enough on getting the work done. These institutions are rightly named as "Greedy Institutions"Sullivan, 2014; Vuga \& Juvan, 2013). Mystery shoppers are part-time professionals working for market research firms conducting various mystery shopping fieldwork (Ford, Latham, \& Lennox, 2011). Mystery shoppers are the watchdogs appointed to observe various store activities as per the expectations of the client firm. Mystery shopping is practiced in various fields such as marketing, banking, insurance, retail, service, entertainment, 
government, etc to measure customer experience (Program, 2017). Though this concept originated during the year 1940 it has grown in leaps and bounds in recent years (Calvert, 2005). Mystery shopping used in the digital platform is bringing in new contributions to the development of social media, digital marketing, analytical platform, etc. contends (Anand Shankar Raja \& Preethi Sarah, 2018). Mystery-shopping professionals have great job opportunities in various fields and even in the global markets. One of the major components needed for successful mystery shoppers is motivation which comprises of various factors such as prestige, pride, recognition, personal development, etc. and EI which comprises of factors such as appraisal of own emotions, Appraisal of others emotions, regulations of emotion, etc. suggests (Anand \& Anand, 2018; Angayarkanni \& Anand Shankar Raja, 2016).

There is a very rich literature source, which states the importance of motivation and Emotional Intelligence for any working professionals in various fields such as teaching, banking, medical, etc. The researchers have stated that skills such as empathy, motivation, and team building help an employee to give the maximum level of performance within the organization, which increases job satisfaction. (Allison, 2009; Pamela, Severt, \& Dickson, 2010) believes that motivation is a part of Emotional Intelligence, which comprises of factors such as optimism, Initiative, Commitment and the drive to achieve. Thus, there is a need to explore the role of motivation in enhancing job satisfaction when mediated by Work-life Balance (WLB) among mystery shoppers (marketing professionals) (Smith, 2010), creating an impact on Emotional Intelligence. Mystery shopping industry is now filled with women professionals for whom WLB is very important. Angayarkanni and Anand Shankar Raja (2015), asserts that ghost shoppers automatically intend to lose their self-motivation and contribute poorly to work performance which reduces job satisfaction, motivation from external environment (superiors) is important which gives a sense of satisfaction

Schutte et al. (1998) initially were the pioneers in the development of a scale to measure Emotional Intelligence. The researchers initially explored 62 items using factor analysis and as a result, 33 items were loaded with factor loadings, more than 0.40 and the reliability was high. The theoretically derived constructs were awareness of emotion, outlook on life, depressed mood, ability to regulate emotions and impulsivity. (Gignac, Palmer, Manocha, \& Stough, 2005) took an initiative to examine the scale developed by Scuttle. Data collection was from 367 participants out of which 107 males, 257 females, 3 unreported. Certain constructs such as self-appraisal, regulation of self-emotion, emotional utilization in problem-solving were the results. Emotional regulation of others and expression of emotions were not identified. (Macdonald \& Maclntyre, 1997), developed the Generic Job Satisfaction Scale "GJSS". This scale was tested on a wide range of various occupational groups. Initially, 44 scale constructs were present which was reduced to 10 items defining one factor. The researcher in the dissertation has stated high reliability of .82 indicating reliability values to be high. (Nelson, Hozak, Albu, \& Thiel, 2015) explored the job satisfaction of nurses and used GJSS to measure work satisfaction in Jamaica. Out of the 10 items, nine items were treated as the latent variables for this research. The CFA run by the researcher and the mode was a good fit. Work-life balance has been explored in the context of Turkish working people and men in order to develop and validate the scale construct and for this purpose; the data was drawn from 274 respondents. Cronbach's alpha and the composite reliability value were close to .90 , which was more accepted in the second study where $(\mathrm{N}=356)$. This scale has 8 constructs. Thus, this scale has been used to measure the WLB of mystery shoppers. In this process, various variables were considered for the CFA (work-family conflict, family-work conflict, work-life balance, and life satisfaction (Taşdelen-Karçkay \& Bakalım, 2017).

\section{Scale Usage}

In this research, work four questionnaire instruments have been adapted to be used for mystery shoppers. For measuring the Emotional Intelligence of mystery shoppers, Shuttle's (Self-Report Emotional Intelligence Inventory) scale is used. This scale has been used in various contexts amongst international students (Kim, 
Wang, \& Ng, 2010), American college students (Gong \& Paulson, 2018), Iranian EFL learners (Skourdi, Rahimi, \& Bagheri, 2014), Medical students (Ibrahim et al., 2017), etc. This scale contains 62 items, framed from the ground theory on Emotional Intelligence developed by (Mayer \& Salovey, 1993; Mayer, Salovey, \& Caruso, 2004; Salovey \& Grewal, 2005). From the scale development and validation process, 33 items (SSREI) Kirk, Schutte, and Hine (2008) and Schutte et al. (1998) were loaded with high factor loadings and were given name tags. Since this scale was explored across many professions to measure Emotional Intelligence, the same has been used for mystery shopping professionals. Deci and Rayan have made a major contribution in developing the concept of motivation (Deci \& Ryan, 2015; Gagné \& Deci, 2005; Ryan \& Deci, 2000) and giving shape to it and hence this scale is used to explore the intrinsic and extrinsic motivation of mystery shoppers. The 18 scale constructs of Naderi, Wechsung, Polzehl, and Möller (2014), Symonds and Russell (2018), Tremblay, Blanchard, Taylor, Pelletier, and Villeneuve (2009) is suitable for a mystery-shopping professional as both the types of motivation is needed and this scale is explored by many researchers in the past. The most important component for any working professional is "job satisfaction" thus; to measure JS the scale developed by Scott Macdonald \& Peter Maclntyre called the "Generic Job Satisfactions Scale" GJSS has been used by (Macdonald \& Maclntyre, 1997). This scale consisted of 44 items, which were reduced to 10 after factor analysis. With regard to Work-Life Balance, the scale used for this research is developed by (Taşdelen-Karçkay \& Bakalım, 2017). Helvaci (2017) used the WLB scale on academicians (N= 195 academicians) (78 female, 117 male) working at the Uşak University.

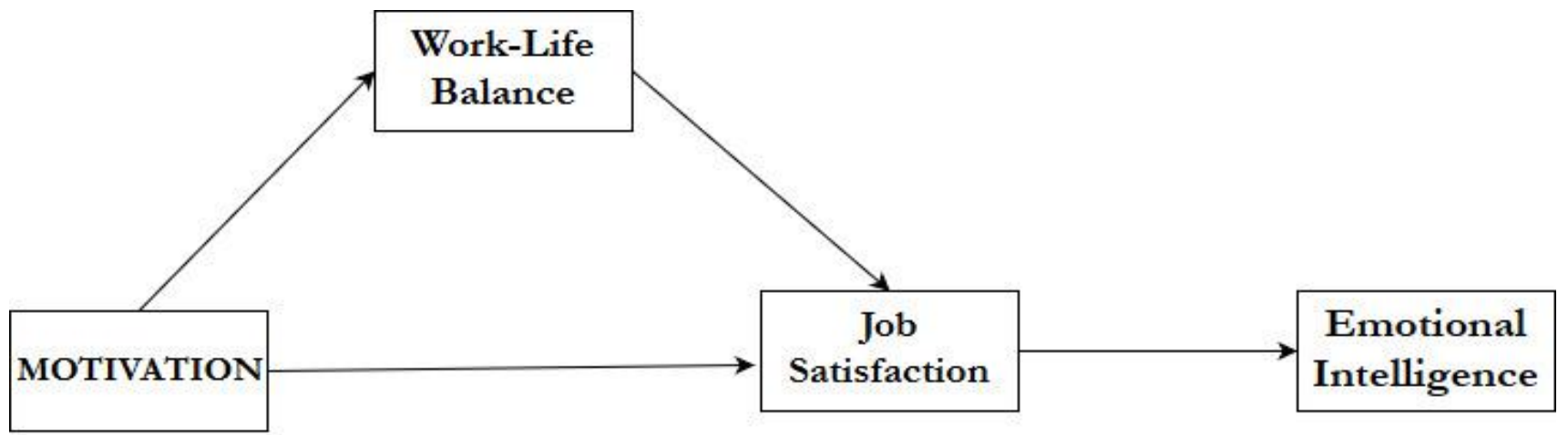

Model explaining the logical relationship in enhancing Job Satisfaction through motivation and Work-Life Balance (WLB) and the overall impact on Emotional Intelligence of Mystery Shoppers.

Model created by Dr Anand Shankar

Raja M, Assistant Professor (Commerce), CHRIST (Deemed to be University)

Figure 1 - Chart showing the Theoretical Framework and hypothesis framing

\section{Hypothesis}

The following hypothesis has been framed based on SLR and Meta-analysis (Delgado-Rodríguez \& SilleroArenas, 2018; Harrison, 2011). This research considers correlational hypothesis considering the claim that mystery shoppers job is very rigid and has no scope for enhancing job satisfaction and explanatory hypothesis considering the inter-relationship between the study variables leading to cause and effect (Crawford, 1949; Shaffer, 2002; Wilcox, 2012). Thus, the following hypothesis is a combination of both. It has to be highlighted that the hypothesis need not be framed always based on past literature works. For a new research dimension, it is purely based on the assumptions of the researcher. Research on mystery shoppers with 
reference to the four-study variable is new and there is no past research work connecting the entire variable and hence the hypothesis is purely based on researchers comfort zone.

H1: There is a strong relationship between motivation and Work-Life Balance of mystery shoppers

H2: Work-Life Balance helps to enhance the job satisfaction of mystery shoppers

H3: Motivation and Work-Life Balance enhances the Job Satisfaction of mystery shoppers

H4: Emotional Intelligence if enhanced is there is a positive correlation between motivation, WLB and Job Satisfaction

H5: Because of the rigid nature of work, mystery shopper's job satisfaction is negative

\section{Research Method}

This research is an initiative to respond to the real-life problems faced by market research firms and mystery shoppers. Thus, this practical insight to solve the problems associated with motivation, Work-Life Balance, job satisfaction and Emotional Intelligence is applied research in nature (Malhotra \& Birks, 2006; Ritchie \& Spencer, 2010). To answer the questions and to draft decisions for policy framing subjected to the study variables applied research is the base. Using social media platform the researchers collected data from mystery shoppers. Social media like pages have become famous in the recent past where there are pages created for sharing information, common interest and goals and one such platform is like pages for mystery shoppers. Thus, mystery shopping like pages in Facebook (Rife, Cate, Kosinski, \& Stillwell, 2016), Kosinski, Matz, Gosling, Popov, and Stillwell (2015) has given an opportunity to collect data from widely registered mystery shoppers from across the world. Thus, the scope of the study is not concerned with one geographical location it is a universal phenomenon. To put it in simple words it is an actual representation of the population. Data was collected from $(N=348)$ mystery shoppers who specialize in various industries through social media. An EFA and CFA have been employed for the data analysis. The software used to run the CFA is AMOS Blunch (2017), (popularly used multivariate analysis software). Since there are four study variables, it is difficult to study the complex relationship and hence AMOS has been used (Bollen, Rabe-Hesketh, \& Skrondal, 2008; Byrne, 2013; Widhiarso \& Psikologi, 2009).

\section{Exploratory Factor Analysis}

The underlying pattern in the scale constructs is being investigated using a multivariate dimensional reduction technique, and hence there is a need to use EFA (Sa-nga-ngam \& Kurniawan, 2006; Taherdoost, Shamsul, \& Jalaliyoon, 2014), EFA also provides a platform for the researcher to take the best analytical decision. In this context, various factors such as sample size, sample adequacy, rotation, extraction method, factor loadings are given importance (Sakaluk \& Short, 2017). The main of this research is to validate the pre-constructed questionnaires for mystery shopping professionals. For this purpose, proven scale constructs are known as SSREI, GJSS, WEIMS, and WLB have been used. EFA is a statistical tool used in validation studies and hence EFA has been employed (Isabel Izquierdo \& Francisco José, 2014).

\section{Exploratory Factor Analysis for SSREI, WEIMS, GJSS, and WLB}

The EFA was conducted for all the four proven scales, and as a result, the KMO (Kaiser-Meyer-Olkin) Dziuban and Shirkey (1974), Kaiser (1974) and Banu and Duraipandian (2014) Measure of Sampling Adequacy) for SSREI was .665, and the Chi-Square value was 6823.385 indicating Bartlett's Test of Sphericity (Ibm, 2019; Tobias \& Carlson, 1969). After the factor loadings, it was observed that scale constructs such as (E1), (E3), (E5), (E11), (E14), (E15), (E19), (E29) and (E31) which has a commonality value more than .8. Finally, after the PCA using Varimax criteria, the commonly clubbed variables were given name tags such as 
Optimistic, Empathetic emotions, Combating Negativities and Accompanying other emotions. The Cronbach Alpha Cronbach (1951), Reynaldo and Santos (1999) value for SSREI was 790 indicating accepted reliability. KaiserMeyer-Olkin Measure of Sampling Adequacy was .624 and Bartlett's Test of Sphericity 1671.502 indicating a positive value for the EFA. After running EFA, it was found that only six constructs had Eigenvalue more than 1. The nametags given for the factors are Motivation for Triumph includes M12 (.820), M14 (.764). Motivation to be a front-runner includes M4 (.828), M6 (.719) namely. The motivation for Livelihood includes M17 (.809) and M5 (.861) and the last component Feeling Secured includes M16 (.862) and M18 (.860). About GJSS, the KMO value was .749, BTS was .2350 .817 , and the factors were iterated under two tags namely: Refreshed sensation and Acclaim and confident.

\section{Structural Equation Model}

Bollen (2002) and Dillon, Bollen, and Long (2006) have extensively used SEM in Social Science. The latent variables have the power to generalize the study results. Four latent variables are as per the comfort zone of the researcher. Motivation, Work-Life Balance, Job satisfaction and Emotional Intelligence) cannot be measured directly and hence there is a need for connecting latent variables (Schreiber et al., 2013). Since all the scale constructs are already proven, Factor Analysis (FA) cannot be performed but an EFA is performed to check the factor loadings. In CFA, it is important to consider the number of factors and the pattern of factor loadings (Curran, West, \& Finch, 1996). Based on the factor loadings in the EFA certain constructs were removed before proceeding with CFA. The research questions raised and the hypothesis framed in this research will be answered by the outputs of the SEM model (Suhr \& Ph, 1999). To deal with multiple regressions SEM is used and the most suitable software is AMOS Bacon (1997). The factor structure of the entire four-study variable is explored in the form of SEM using a Confirmatory Factor Analysis (CFA).

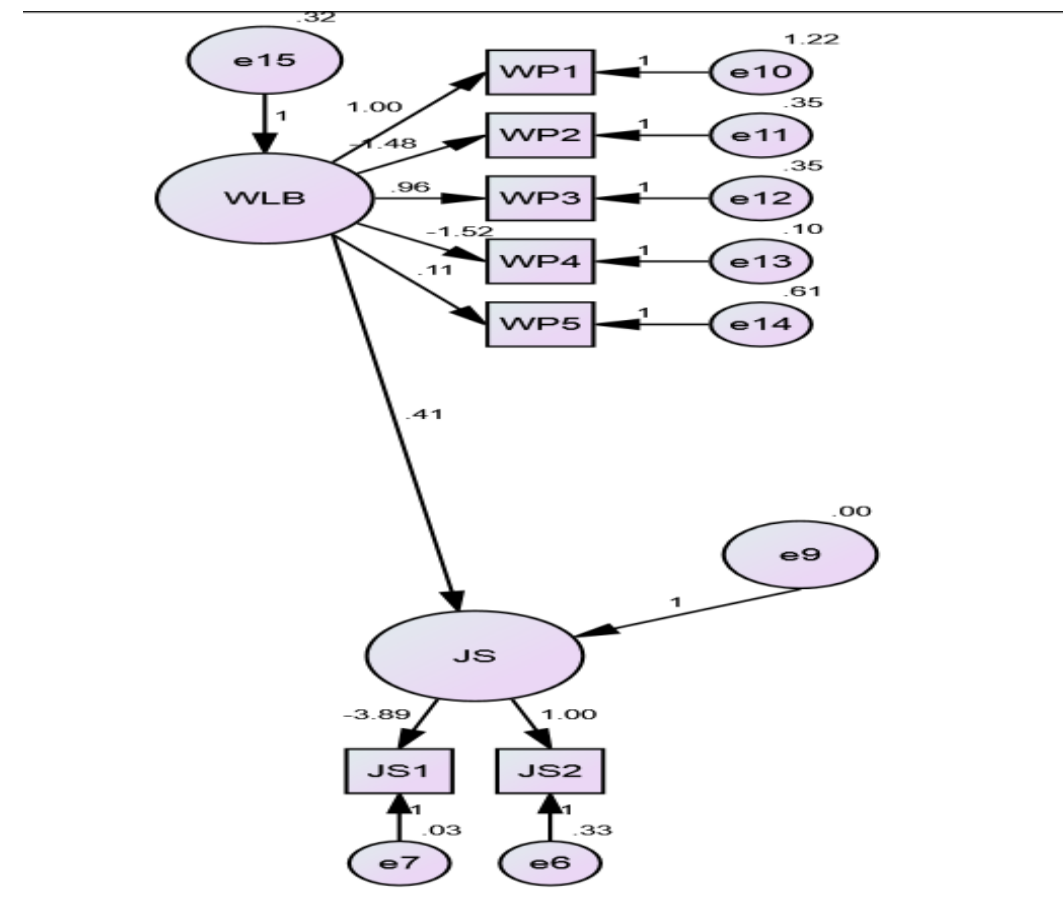

Figure 2 - relationship between Work-Life Balance and Job Satisfaction 


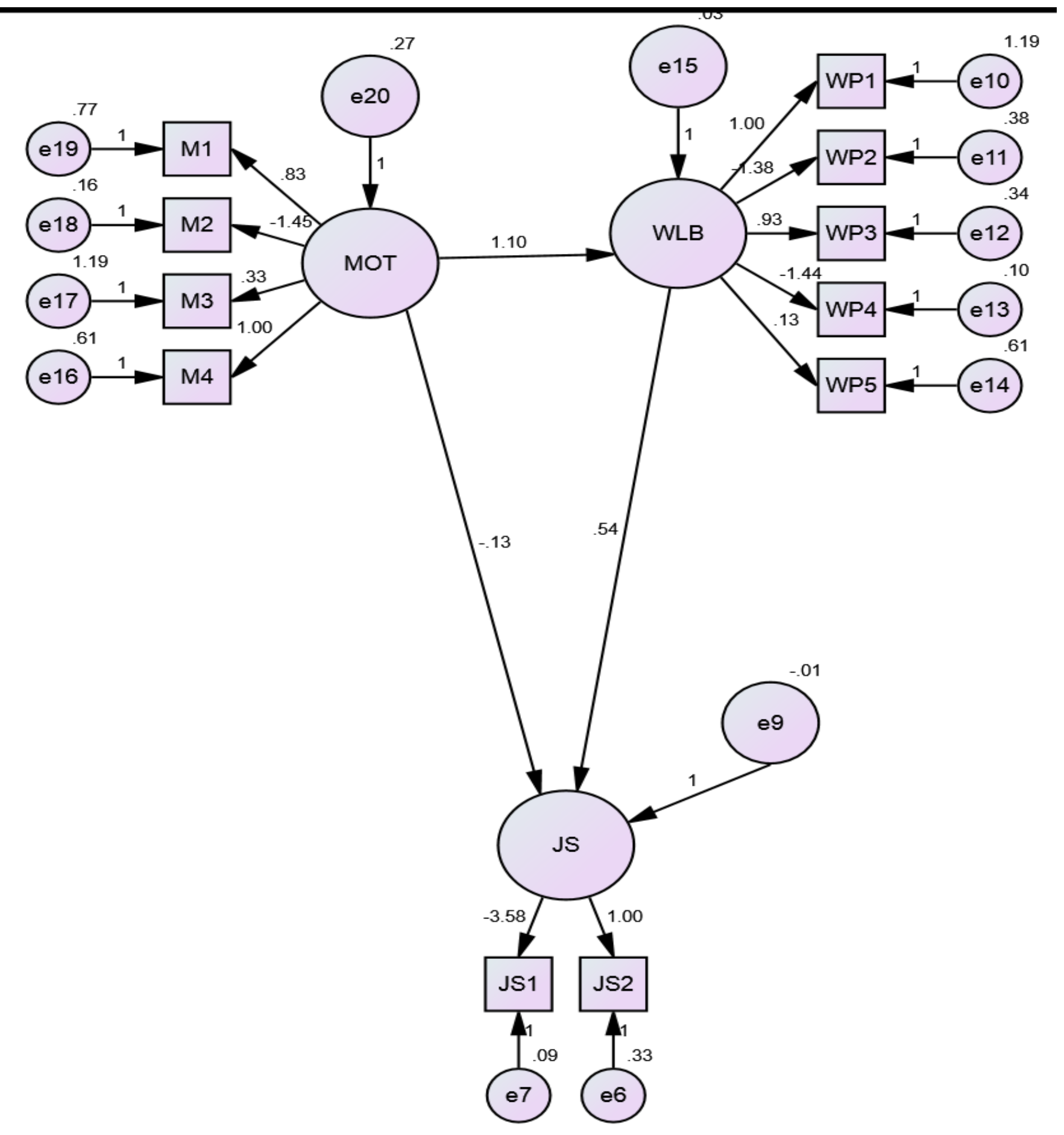

Figure 3 - the impact of motivation on Job Satisfaction mediated through Work-Life Balance 


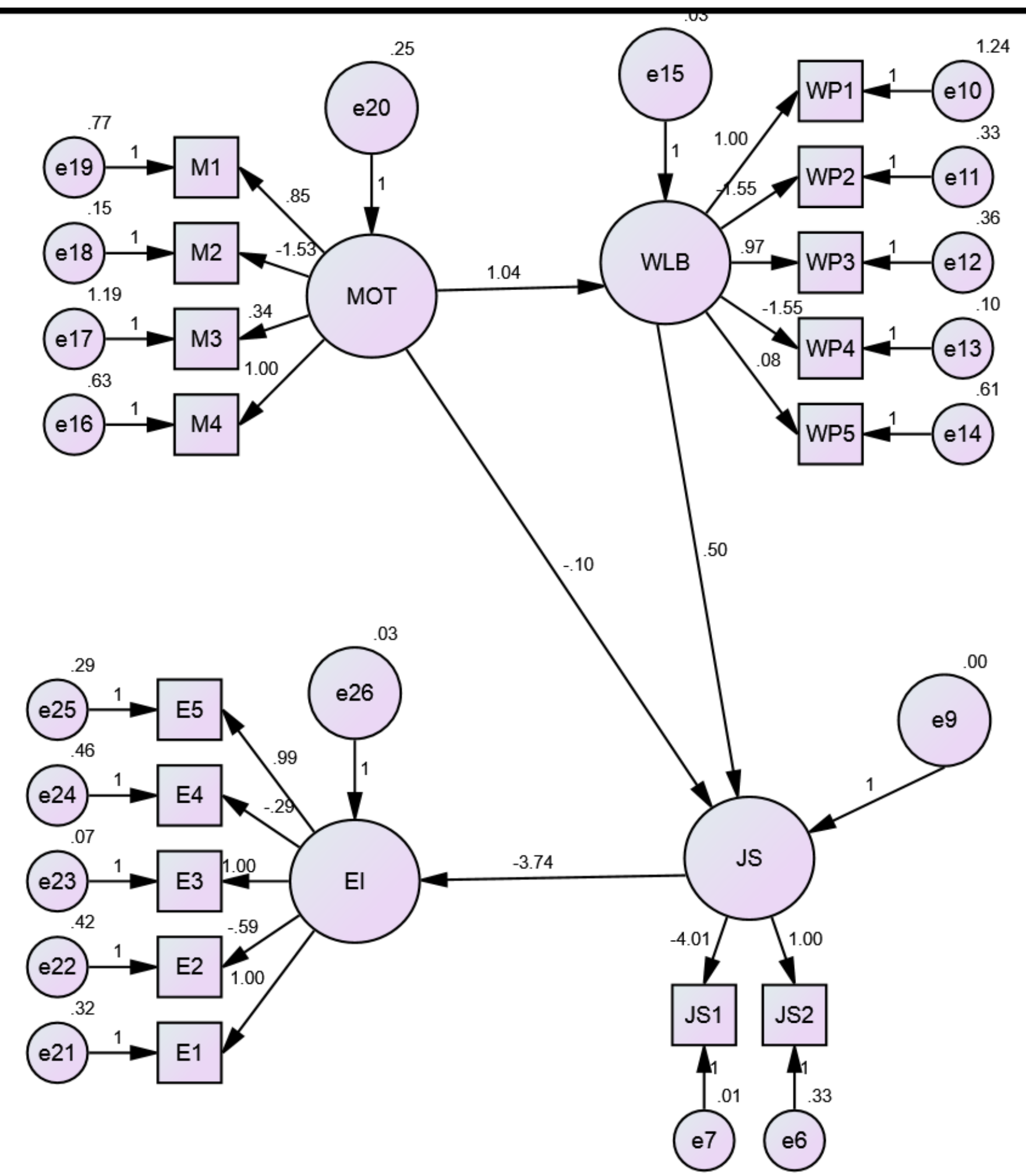

Figure 4 - mediated effect of Work-Life Balance through motivation and Job Satisfaction and its impact on Emotional Intelligence 


\section{Discussion}

Researchers working in the domain of social science are interested to quantify the qualitative variables using suitable tools and hence they use casual modeling (path analysis to compare the strength and understand the relationship) (Keith \& Keith, 2019; Wuensch, 2015). In this research, there is a thirst to examine the causal relationship between many independent variable and dependent variable and hence it is a multivariate analysis (Hebebrand, 2010; Tabachnick \& Fidell, 2012). Multivariate analysis is used in much modern applied research. The relationship established between all the four study variables is due to the comfort zone of the researcher. All the theoretical relationship stated before in hypothesis framing is tested in this process. A system of regression equations called the "Structural Equation Model" is the tool used for the analysis of data for statistical modeling (Barnett, Neter, \& Wasserman, 2006; Golden, 2015; Shmueli, 2009). Based on the newly established causal relationship new theories and concepts can be established by explaining the relationship between the variables. Figure 1.C depicts the impact of variable A (Motivation) on variable B (Work-Life Balance) and the impact of WLB on variable C (Job Satisfaction) and the overall impact on variable D (EI). Thus, this composition of multiple variables is formulated through Linear Regression Equations and hence SEM is called Linear Structural Relations (Bentler \& Weeks, 1980; Markus, 2012). There are four exogenous variables in this research denoted by straight arrows pointing from them to another (each other). Work-Life Balance (WLB) is the mediating variable in this research. The path diagrams are very important as it shows the relationship between the study variables (Boker \& McArdle, 2014; Curran et al., 1996). In this, research the path coefficients are:

\section{Motivation $\rightarrow$ Work-Life Balance is 1.04}

McCutcheon (2014) highlights that WLB is a serious issue and a key subject matter for every working professional. Interestingly people perform other activities rather than work which might bring an imbalance balance between two. Most surprisingly many researchers have explored the impact of WLB on motivation but in this research, it is quite different. As a researcher, I feel that one has to be motivated by him/her and by the family members giving positive energy to balance work and family. Thus, priority is motivation. As proposed in the hypothesis framework this relationship has been proved and shows a very positive impact. First, spy-shoppers are part-time workers and work on unusual and unexpected situations based on sudden demand. The inner aspiration to work and at the same time to spend time with family and for other personal commitments should be a spark of motivation. The motivation here is a set of energetic force, which should energize a person to explore new things. Some mystery shoppers get motivated purely based on intrinsic influence and this is only for personal satisfaction and enjoyment highlighting the importance of "Intrinsic Motivation" (Reiss, 2012). If they are considering only their personal enjoyment then obviously, they miss WLB. Caregiving, sibling relationships, and cultural expectations and the emotional display will remind the mystery shoppers to spend time for family and these factors are purely extrinsic motivational factors (Fox \& Calkins, 2003). The choice is now based on individual mystery shopper on how he/she has to be motivated.

\section{Work-Life Balance $\rightarrow$ Job Satisfaction is .50}

Haar, Russo, Suñe, and Ollier-Malaterre (2014) conducted an extensive study by collecting data from various types of respondents and found that WLB has a strong impact on job satisfaction and life-satisfaction. Malik, Wan, Dar, Akbar, and Naseem (2014) collected data from respondents working in business schools and found that job satisfaction and benefit is influenced by WLB. In the case of mystery shoppers, also this is true. Being part-time professionals, they do have to spend time with family and work only as per flexibility. This universal phenomenon is true even in the case of hush-hush shoppers. Equal satisfaction with work and family is important for a person (Greenhaus, Collins, \& Shaw, 2003). The new shoppers who are keen enough to learn more and explore adventurously spend extra time at work and have no time to spend with family thus 
WLB in early careers are also highly possible (Sturges \& Guest, 2004). This is true! Any mystery shopper for that matter has to initially work hard and struggle to get quality assignments.

\section{Motivation $\rightarrow$ Job Satisfaction is -1.0}

Hayati \& Caniago (2014) in his research says that motivation and job satisfaction leads to positive work performance. If this is true then there is a relationship between motivation and job satisfaction in the first place. Stringer, Didham, and Theivananthampillai (2011) state that extrinsic motivation has a negative effect on job satisfaction. Thus, motivation has different connotations based on internal and external influence, which further influences job satisfaction. In some research, it is positive and in some it is negative but in the case of mystery shoppers, it is negative. Mystery shopper's job satisfaction need not be dependent only on motivation because there is no possibility of motivation due to pay, organizational culture, etc. This might have been the reason why there is a negative impact between motivation and job satisfaction.

\section{Job Satisfaction $\rightarrow$ Emotional Intelligence is $\mathbf{- 3 . 7 4}$}

Sy, Tram, and O'Hara (2006) studied the relationship between employee and manager and found that EI had a positive impact on job satisfaction. Anari (2012) found that amongst the teachers there is a strong influence of EI on job satisfaction. Most of the research work done amongst various professionals claim that there is a strong relationship between EI and Job Satisfaction. However, with regard to mystery shoppers, there is a negative relationship. The other professionals have routine work and meet the same people every day but in the case of mystery shoppers, the work pattern differs and they have to meet a variety of people during the mystery shopping fieldwork. Thus, there might be a high rate of fluctuation in emotional intelligence, which is further being influenced negatively by job satisfaction. The SEM includes the latent variable and the observed variable as seen in the conceptual model represented in Figure 1.a expressing the linear relationship. Motivation, WLB, Job Satisfaction, and EI are the observed variables and error terms are drawn as latent. Estimation of the error term directly is not possible. One head-arrow is inserted between variables showing the cause and effect impact. The conceptual model is useful to understand the complex phenomena with reference to the relationship between the variables carefully picked up from the past literature reviews. The framed hypothesis is now to be tested using an SEM (CFA) by solving a set of equations. The output might be negative or positive which is left open to the universe for acceptance or suggestions and feedback. The model is evaluated based on the fit-statistics considering the Goodness-of-fit-indexes. Sample size modeling of Krejcie and Morgan (1970), MacCallum, Widaman, Zhang, and Hong (1999) and Wolf, Harrington, Clark, and Miller (2013) plays an important role in the hypothesized model and hence to know if the sample size was adequate AGFI and GFI values are important. The value of GFI was .856 and for AGFI it was .978 indicating positive sample adequacy. The other fit index is given below in table No 1.D (Goodness of Fit Index GFI) (Cheung \& Rensvold, 2002; Hoelter, 1983; Marsh, Balla, \& McDonald, 1988). The regression weights represent the magnitude of the association between variables. The factor loadings called the regression weights are important in AMOS output (Nimon \& Oswald, 2013). Optimistic (M1) Scheier and Carver (1993), Empathetic emotions (M2) Ioannidou (2008), Ross (2017), Combating Negativities (M3) and accompanying other emotions (M4), Extrovert personality (M5) represents Emotional Intelligence. It is evident that optimistic feeling and combating negativities are the most important components shaping the EI of mystery shoppers. This is much true because mystery shoppers have to be strong and brave enough to do the mystery shopping assignment, which is very much unexpected. Each situation for a mystery shopper is a new challenge. With regard to Job Satisfaction (JS2) Acclaim and confidence Bénabou and Tirole (2002) and Vealey, Chase, Block, and Cooley (2018) contributes the most towards JS this is true because the monetary benefits from individual assignment is not a great amount but, if mystery shoppers have confidence in themselves then it's easy to be a champion in this profession. Considering the individual variables and the relationship between them from the study, it is understood that motivation leads to WLB and creates a 
positive impact on the mystery shoppers to have a balance between family and work. Motivation creates a healthy lifestyle through WLB (Berman, 2002). Though motivation does not have a direct impact on job satisfaction, it is high when it is being mediated through WLB. The overall impact on EI is negative because EI is an independent factor according to me (researcher of this study). For other professionals, EI would enhance through job satisfaction, WLB, and Motivation but for mystery shoppers, it is obvious that EI is totally a separate variable, which cannot be enhanced through JS, WLB or motivation. Mystery shoppers EI is a deep sea filled with mysterious feelings, which cannot be easily regulated. Based on the results of this study it is concluded that mystery shoppers motivations (internal and external) enhance the WLB to have a perfect balance between mystery shopping field work and personal life. However, motivation cannot enhance job satisfaction because whatever internal or external motivational factor influences a mystery shopper the final influence is because of the nature of work of mystery shoppers.

Table 1 - Goodness of Fit Index (GFI) for the Hypothesized model

\begin{tabular}{lcc}
\hline \multicolumn{1}{c}{ Fit statistics } & Obtained & Recommended \\
\hline$x^{2}$ & 194.654 & - \\
df & 41 & - \\
$x^{2}$ Significance & 0.000 & $\mathrm{p}<=0.05$ \\
$x^{2} /$ df & 4.773 & $>0.90$ \\
GFI David A. Kenny (2012) & .934 & $>0.90$ \\
AGFI Aima, Surip, \& Susilo, (2015) & .892 & $>0.90$ \\
NFI Lewis (2017) & .864 & $>0.90$ \\
RFI McDonald \& Marsh (1990) & .767 & $>0.90$ \\
CFI Marsh \& Balla (1994) & .872 & $>0.90$ \\
TLI Hu \& Bentler (1998) & .825 & $>0.90$ \\
RMSEA/RMR Kenny, Kaniskan, \& McCoach (2015) & $.087 / 0.40$ & $<0.05 /<0.02$ \\
\hline
\end{tabular}

\section{Practical Implications}

Mystery shoppers are not just freelancers, they are professionals working indirectly with a client firm through marketing research firms to frame strategies and managerial decisions (Latham, Ford, \& Tzabbar, 2012). The work of a mystery shopper should never be underestimated because the efforts, which they put in executing each fieldwork, are enormous. Mystery shoppers specialize in one file as well as they get exposure in various fields depending on the requirement (Lowe, 1997). They face many problems such as over workload, timely submission of assignments, fear in meeting new faces, less payment for quality work, etc. (Anand \& Anand, 2018). Mystery shoppers are not recognized for the work done, as the market research agents do not maintain a long-lasting relationship. All these issues cause emotional pain and reduce the level of motivation (Angayarkanni \& Anand Shankar Raja, 2016). As an effect, there is reduced job satisfaction. Unexpected assignments and work cause work-life balance issues. Especially the women mystery shoppers who are expected to stay with family when required conduct mystery-shopping assignments and lose touch with family members. Mystery shoppers should consider the following recommendations:

- Ghost shoppers should specialize in one area based on interest and passion and be known for quality work. They should never take up too many assignments at the same time, which might cause stress. They should be brave when meeting new people; self-motivation is the best medicine to handle touch people during the time of mystery shopping assignment. Most importantly, they should take pride in being a mystery shopping professional and understand the truth that this profession is designed in such a way it maintains no relationship with the top management and co-workers. 
- Telephonic mystery shopping assignments can be taken when there is a need to spend time with family. Mystery shoppers should look forward to popular market research agencies for assignments, as the payment will be fancy and high. One good assignment is better than too much small unrecognized work.

- Cultivation of positive emotions is important and even more important is understanding the emotions of others. They should always self-celebrate the mystery shopping results without expecting appreciation from family members all the time.

- Consider the mystery-shopping profession to be a hobby rather than full-time employment. Mystery shoppers should enjoy each minute of mystery shopping work, as it is an opportunity to learn many new endeavors in terms of research, report writing, logical thinking, etc.

- Hush-hush shoppers should check and double check before being enrolled with a market research firm. Look for recognized branded firms in the market, which gets good client projects.

- Motivation, Emotional Intelligence, Job satisfaction, and Work-Life Balance is all in the hands of mystery shoppers. Hence, this wonderful profession should be accepted as such with a few negativities. Mystery shoppers should plan their work schedule so that they have a perfect balance for work and personal life. Instead of routine mystery shopping, the mystery shoppers can prefer shopping assignments based on alternative work pattern (Monday-Wednesday-Friday).

- As freelancing jobs have become an obvious choice for most of the working class due to high competitiveness mystery shopping has grown in this phase. However, there is steady growth and world opportunities for mystery shoppers a crisis in this sector is not a new phenomenon because of its undefined job roles. Nevertheless, what has triggered the volley of questions from mystery shoppers is because of the very less pay and no scope for being recognized for quality work done.

- In the backdrop of all these problems that are plaguing mystery shoppers job, the agrarian challenge is to improve the overall job satisfaction. Thus, the problem stated above briefly is about the mediating effect of Work-Life Balance (WLB) in enhancing job satisfaction through motivation and creating a positive impact on EI. While many problems ail in the mystery shopping profession these four study variables are the most important one.

- One of the major key recommendations is for the Mystery Shoppers Providers Association to design rules and regulations to enhance the job satisfaction of mystery shoppers through well-defined training and Development programs.

\section{Future Research}

- This research work made use of proven scale constructs and hence the future researchers can develop scale only for mystery shopping professionals. Several attempts have been done on exploring the factors using EFA but there is no scale developed for mystery shoppers. Thus, despite just using EFA the future researchers can develop a separate scale for ghost shoppers.

- A most important component to be explored is "Stress Management" and "Coping Strategies" (Krohne, 2004; Park \& Folkman, 1997). Future researchers can study the problems and stress faced by mystery shoppers. Since mystery shoppers are part-time professionals there are no training and development programs given to mystery shoppers and hence market research firms can take efforts to work on T and D (Training and Development) (Aguinis \& Kraiger, 2009; Whiteside, 1993). 
- Framing modules for Training and Development for mystery shopping professionals can be a separate project taken by institutions specializing in HRM.

- Mystery shoppers can be used to explore employee engagement within the organization through spy work, which can be used for taking training and development decisions.

- In the organizational climate context, mystery shoppers can be used to explore the intervention of LGBTQ employees Göçmen \& Yılmaz (2017) and its impact on organizational members.

- Though countries like India, China, USA has progressed, there is a high rate of child labor and exploitation of women employees within the organization. This problem can be solved by employing mystery shoppers.

- Future researchers can explore the in-depth role of emotional intelligence amongst mystery shoppers to check the impact on behavior, life satisfaction, cognition, social functioning, occupational stress, etc.

\section{Conclusion}

Behavioral perspectives of employees are very strong determinants in framing strategic decisions in HRM (Wright \& McMahan, 1992). The framework has to be well developed to understand the behavioral perspectives for mystery shoppers and hence this study considers the most important variables in HRM. The job of a Mystery shopping profession is not a cakewalk because mystery shoppers have to deal with a curveball, which is full of difficulties. The changing business landscape has resulted in a very strong need for career development (Baruch, 2006). The world is changing in a very fast phase and organization is anticipating the changes (Steers et al., 2013). In addition, the demographic influence is a major challenge for all organizations. Despite this, the market research firms providing employment opportunities should be ready to meet the changes, which are unexpected. Even though mystery shoppers might be successful, in their career, they should also be ready to face stiff competition and they have to self-train themselves in various aspects to be competitive in the job market. Mystery shoppers being freelancers should put their hearts where their passion is to become successful in the market research industry. Everything which mystery shopping profession gives should be taken as a gift and as an opportunity to witness a great experience which leads to SWB (Subjective Well-Being) (Fullagar \& Kelloway, 2009). Being part-time professionals the biggest challenge for mystery shoppers is allocating time.

Filtering out what is important and what not is a major task for every mystery-shopping professionals. Mystery shoppers can glorify themselves in this profession, as they are their own boss and can end up giving a lot more for this profession, psychologically emotionally and physically. Mystery shoppers are the Zen warriors! They have to put efforts to conquer formidable in the most competitive industry. Hare-racing tales are the experiences of every mystery shopper, which has positive and negative factors, and most importantly, it is a patient wait for claiming monetary benefits for the hard work. The role of a mystery shopper is to measure customer satisfaction, experience and other aspects related to service quality (Mosch \& Fürderer, 2012). Only if the mystery shoppers take efforts to conduct mystery-shopping field work with keen determination the outcome will be fruitful. For this, the mindset and cognitive sense have to be well balanced in a peaceful state for which Emotional Intelligence becomes a primary prerequisite. Mystery shoppers have to first understand the emotions of others then react based on the situation. This is termed as "Understanding others emotions" Tomasello, Carpenter, Call, Behne, and Moll (2005) where the mystery shopper knows the expectations of other individuals and carefully communicates based on the person's mindset, attitude, behavior, etc. (Angayarkanni \& Anand Shankar Raja, 2015). Talking about mystery shoppers own emotions it is called "Regulatory of own emotions" which means ghost shoppers should create space for themselves to 
think where they have to improve and where they have to keep their mind calm and in which way. This practice will bring a lot of success for mystery shopping professionals. It is very difficult for a mystery shopper to be satisfied with the job but it all depends on how a mystery shopper works without expectation and recognition from the external world. The nature of the mystery shopping job is secret, which has to be maintained and there is no organizational climate, co-workers relationship, communication with top supervisor, etc. and of the communication is through email. There is nothing much beyond the payment, which a mystery shopper gets after each assignment. Thus, job satisfaction can be enhanced only through motivation and Work-life Balance (WLB). Balancing work and family is a major concern for most professionals and even for mystery shoppers. Just because they are part-time workers, it does not mean that WLB is important for them. In-fact mystery shopper's work during all the unexpected circumstances and sometimes they are asked to repeat the same fieldwork a couple of times, which might affect them. As a concluding remark, it has to be mentioned that mystery shoppers should be an extrovert, optimist, hardworker to be a successful mystery shopping professional. At the same time, they have to control their emotions, which might not lead to depression and stress spoiling their career and personal life. Future researchers conduct research studies on stress and coping strategies exclusively for mystery shopping professionals.

\section{References}

Adil, M. S., \& Ab Hamid, K. B. (2019). The Relationships between Leader Creativity Expectations, Intrinsic Motivation, and Creative Performance. SEISENSE Journal of Management, 2(2), 58-68. doi:10.33215/sjom.v2i2.123

Aguinis, H., \& Kraiger, K. (2009). Benefits of training and development for individuals and teams, organizations, and society. Annual Review of Psychology. doi:10.1146/annurev.psych.60.110707.163505

Albertsen, K., Rafnsdóttir, G. L., Grimsmo, A., Tómasson, K., \& Kauppinen, K. (2008). Workhours and worklife balance. Scandinavian Journal of Work, Environment and Health, Supplement.

Allison, P. B. (2009). Mystery shopper motivations and the presence of motivation crowding. Dissertation Abstracts International Section A: Humanities and Social Sciences.

Anand Shankar Raja, M., \& Preethi Sarah, J. P. (2018). Social media marketing and ghost shopping approach; a new business tool. International Journal of Mechanical Engineering and Technology, 9(1).

Anand, S. R. M., \& Anand, R. B. (2018). Influence of Demographic Constructs on Motivation and Job Satisfaction among Mystery Shoppers. International Journal of Management Studies. doi:10.18843/ijms/v5i3(3)/02

Anari, N. N. (2012). Teachers: Emotional intelligence, job satisfaction, and organizational commitment. Journal of Workplace Learning. doi:10.1108/13665621211223379

Angayarkanni, R., \& Anand Shankar Raja, M. (2015). Emotional intelligence an essential cause for mystery shoppers. International Journal of Pharmaceutical Sciences Review and Research, 35(2).

Angayarkanni, R., \& Anand Shankar Raja, M. (2016). A study on the logical relationship between emotional intelligence, job satisfaction and motivation among mystery shoppers: A pilot study analysis. International Business Management, 10(6). doi:10.3923/ibm.2016.818.826 
Angerer, J. M. (2003). Job burnout. In.

Bacon, L. D. (1997). Using Amos for structural equation modeling in market research.

Banu, A. R., \& Duraipandian, K. (2014). DEVELOPMENT OF AN INSTRUMENT TO MEASURE WORK LIFE BALANCE OF IT PROFESSIONALS IN CHENNAI. International Journal of Management.

Barnett, V., Neter, J., \& Wasserman, W. (2006). Applied Linear Statistical Models. Journal of the Royal Statistical Society. Series A (General). doi:10.2307/2984653

Baruch, Y. (2006). Career development in organizations and beyond: Balancing traditional and contemporary viewpoints. Human Resource Management Review. doi:10.1016/j.hrmr.2006.03.002

Bénabou, R., \& Tirole, J. (2002). Self-confidence and personal motivation. In.

Bentler, P. M., \& Weeks, D. G. (1980). Linear structural equations with latent variables. Psychometrika. doi:10.1007/BF02293905

Berman, E. L. (2002). Work/life balance. In.

Blunch, N. J. (2017). Structural Equation Modeling with AMOS. In.

Boker, S. M., \& McArdle, J. J. (2014). Path Analysis and Path Diagrams. In.

Bollen, K. A. (2002). Latent Variables in Psychology and the Social Sciences. Annual Review of Psychology. doi:10.1146/annurev.psych.53.100901.135239

Bollen, K. A., Rabe-Hesketh, S., \& Skrondal, A. (2008). Structural Equation Models. In.

Byrne, B. M. (2013). Structural equation modeling with AMOS: Basic concepts, applications, and programming, second edition.

Calvert, P. (2005). It's a mystery. Mystery shopping in New Zealand's public libraries. Library Review. doi:10.1108/00242530510574138

Cheung, G. W., \& Rensvold, R. B. (2002). Evaluating goodness-of-fit indexes for testing measurement invariance. Structural Equation Modeling. doi:10.1207/S15328007SEM0902_5

Crawford, L. (1949). Hypothesis. Educational Forum. doi:10.1080/00131724909341985

Crompton, R., \& Lyonette, C. (2006). Work-life 'balance' in Europe. Acta Sociologica. doi:10.1177/0001699306071680

Cronbach, L. J. (1951). About Alpha of Cronbach. Psychometrika.

Curran, P. J., West, S. G., \& Finch, J. F. (1996). The Robustness of Test Statistics to Nonnormality and Specification Error in Confirmatory Factor Analysis. Psychological Methods, 1(1), 16-29.

doi:10.1037/1082-989X.1.1.16 
Deci, E. L., \& Ryan, R. M. (2015). Self-Determination Theory. In.

Delgado-Rodríguez, M., \& Sillero-Arenas, M. (2018). Systematic review and meta-analysis. Medicina Intensiva. doi:10.1016/j.medin.2017.10.003

Dillon, W. R., Bollen, K. A., \& Long, J. S. (2006). Testing Structural Equation Models. Journal of Marketing Research. doi:10.2307/3152134

Dziuban, C. D., \& Shirkey, E. C. (1974). When is a correlation matrix appropriate for factor analysis? Some decision rules. Psychological Bulletin. doi:10.1037/h0036316

Ford, R. C., Latham, G. P., \& Lennox, G. (2011). Mystery shoppers: A new tool for coaching employee performance improvement. Organizational Dynamics. doi:10.1016/j.orgdyn.2011.04.002

Fox, N. A., \& Calkins, S. D. (2003). The development of self-control of emotion: Intrinsic and extrinsic influences. In.

Fullagar, C. J., \& Kelloway, E. K. (2009). 'Flow' at work: An experience sampling approach. Journal of Occupational and Organizational Psychology. doi:10.1348/096317908X357903

Gagné, M., \& Deci, E. L. (2005). Self-determination theory and work motivation. Journal of Organizational Behavior. doi:10.1002/job.322

Gignac, G. E., Palmer, B. R., Manocha, R., \& Stough, C. (2005). An examination of the factor structure of the Schutte Self-Report Emotional Intelligence (SSREI) scale via confirmatory factor analysis. Personality and Individual Differences, 39(6), 1029-1042. doi:10.1016/j.paid.2005.03.014

Golden, R. M. (2015). Statistical Pattern Recognition. In.

Goldstein, D. S., \& Kopin, I. J. (2007). Evolution of concepts of stress. In.

Gong, X., \& Paulson, S. E. (2018). Validation of the Schutte Self-Report Emotional Intelligence Scale With American College Students. Journal of Psychoeducational Assessment. doi:10.1177/0734282916669245

Greenhaus, J. H., Collins, K. M., \& Shaw, J. D. (2003). The relation between work-family balance and quality of life. Journal of Vocational Behavior. doi:10.1016/S0001-8791(02)00042-8

Haar, J. M., Russo, M., Suñe, A., \& Ollier-Malaterre, A. (2014). Outcomes of work-life balance on job satisfaction, life satisfaction and mental health: A study across seven cultures. Journal of Vocational Behavior. doi:10.1016/j.jvb.2014.08.010

Harrison, F. (2011). Getting started with meta-analysis. Methods in Ecology and Evolution. doi:10.1111/j.2041210X.2010.00056.x

Hebebrand, J. (2010). New functions for multivariate analysis. Obesity facts. doi:10.1159/000323281

Helvaci, M. A. (2017). THE WORK-LIFE BALANCE OF ACADEMICS. 7(4), 80-85. 
Hoelter, J. W. (1983). The Analysis of Covariance Structures: Goodness-of-Fit Indices. Sociological Methods \& Research. doi:10.1177/0049124183011003003

Ibm (2019). [KMO and Bartlett's Test].

Ibrahim, N. K., Algethmi, W. A., Binshihon, S. M., Almahyawi, R. A., Alahmadi, R. F., \& Baabdullah, M. Y. (2017). Predictors and correlations of emotional intelligence among medical students at King Abdulaziz University, Jeddah. Pakistan Journal of Medical Sciences. doi:10.12669/pjms.335.13157

Ioannidou, F. (2008). Empathy and emotional intelligence: What is it really about? International Journal of Caring Sciences.

Isabel Izquierdo, J. O., \& Francisco José, A. (2014). Exploratory factor analysis in validation studies: Uses and recommendations. Psicothema, 26(3), 395-400. doi:10.7334/psicothema2013.349

Kaiser, M. O. (1974). Kaiser-Meyer-Olkin measure for identity correlation matrix. Journal of the Royal Statistical Society.

Keeton, K., Fenner, D. E., Johnson, T. R. B., \& Hayward, R. A. (2007). Predictors of physician career satisfaction, work-life balance, and burnout. Obstetrics and Gynecology. doi:10.1097/01.AOG.0000258299.45979.37

Keith, T. Z., \& Keith, T. Z. (2019). Path Analysis. In.

Kim, D. H., Wang, C., \& Ng, K. M. (2010). A rasch rating scale modeling of the schutte self-report emotional intelligence scale in a sample of international students. Assessment. doi:10.1177/1073191110376593

Kirk, B. A., Schutte, N. S., \& Hine, D. W. (2008). Development and preliminary validation of an emotional self-efficacy scale. Personality and Individual Differences. doi:10.1016/j.paid.2008.06.010

Kosinski, M., Matz, S. C., Gosling, S. D., Popov, V., \& Stillwell, D. (2015). Facebook as a research tool for the social sciences. American Psychologies. doi:10.1037/a0039210

Krejcie, R. V., \& Morgan, D. W. (1970). Determining Sample Size for Research Activities. Educational and Psychological Measurement. doi:10.1177/001316447003000308

Krohne, H. W. (2004). Stress and Coping Theories. In.

Latham, G. P., Ford, R. C., \& Tzabbar, D. (2012). Enhancing employee and organizational performance through coaching based on mystery shopper feedback: A quasi-experimental study. Human Resource Management. doi:10.1002/hrm.21467

Lowe, P. (1997). Mystery shoppers [3]. In.

MacCallum, R. C., Widaman, K. F., Zhang, S., \& Hong, S. (1999). Sample size in factor analysis. Psychological Methods. doi:10.1037/1082-989X.4.1.84

Macdonald, S., \& Maclntyre, P. (1997). The generic job satisfaction scale: Scale development and its correlates. Employee Assistance Quarterly. doi:10.1300/J022v13n02_01 
Malhotra, N. K., \& Birks, D. F. (2006). Marketing Research: An Applied Approach.

Malik, M., Wan, D., Dar, L., Akbar, A., \& Naseem, M. A. (2014). The role of work life balance in job satisfaction and job benefit. Journal of Applied Business Research. doi:10.19030/jabr.v30i6.8879

Markus, K. A. (2012). Linear Causal Modeling with Structural Equations. Structural Equation Modeling: A Multidisciplinary Journal. doi:10.1080/10705511.2012.713284

Marsh, H. W., Balla, J. R., \& McDonald, R. P. (1988). Goodness-of-Fit Indexes in Confirmatory Factor Analysis: The Effect of Sample Size. Psychological Bulletin. doi:10.1037/0033-2909.103.3.391

Maslach, C., Schaufeli, W. B., \& Leiter, M. P. (2001). Job urnout. Annual Review of Psycholoy. doi:10.1146/annurev.psych.52.1.397

Mayer, J. D., \& Salovey, P. (1993). The intelligence of emotional intelligence. Intelligence.

Mayer, J. D., Salovey, P., \& Caruso, D. R. (2004). Emotional intelligence: Theory, findings, and implications. In.

Meadows, J. (2017). Stress. In.

Mosch, A., \& Fürderer, K. (2012). Mystery Shopping. BankFachklasse inklusive Online Prüfungstraining. doi:10.1365/s35139-011-0067-4

Naderi, B., Wechsung, I., Polzehl, T., \& Möller, S. (2014, 2014). Development and V alidation of Extrinsic Motivation Scale for Crowdsourcing Micro-task Platforms.

Nelson, J. W., Hozak, M. A., Albu, A., \& Thiel, L. (2015). Nurse Job Satisfaction Research: A Literature Review, 2006-2011. Virginia Henderson Global Nursing e-Repository, 2006-2011.

Nimon, K. F., \& Oswald, F. L. (2013). Understanding the Results of Multiple Linear Regression: Beyond Standardized Regression Coefficients. In.

Pamela, A., Severt, D., \& Dickson, D. (2010). A conceptual model for mystery shopping motivations. Journal of Hospitality Marketing and Management. doi:10.1080/19368623.2010.493077

Park, C. L., \& Folkman, S. (1997). Meaning in the context of stress and coping. Review of General Psychology. doi:10.1037/1089-2680.1.2.115

Program, M. S. (2017). Designing a ‘ Smarter’ Mystery Shopping Program. (June).

Reiss, S. (2012). Intrinsic and Extrinsic Motivation. In.

Reynaldo, J., \& Santos, A. (1999). Cronbach's Alpha: A Tool for Assessing the Reliability of Scales. Extension Information Technology.

Rife, S. C., Cate, K. L., Kosinski, M., \& Stillwell, D. (2016). Participant recruitment and data collection through Facebook: the role of personality factors. International Journal of Social Research Methodology. doi:10.1080/13645579.2014.957069 
Ritchie, J., \& Spencer, L. (2010). Qualitative data analysis for applied policy research. In.

Ross, J. (2017). You and me: Investigating the role of self-evaluative emotion in preschool prosociality. Journal of Experimental Child Psychology. doi:10.1016/j.jecp.2016.11.001

Ruth Eikhof, D. (2007). Introduction: What work? What life? What balance? Employee Relations. doi:10.1108/er.2007.01929daa.001

Ryan, R. M., \& Deci, E. L. (2000). Intrinsic and Extrinsic Motivations: Classic Definitions and New Directions. Contemporary Educational Psychology. doi:10.1006/ceps.1999.1020

Sa-nga-ngam, P., \& Kurniawan, S. (2006). An investigation into older people's browsing activities. PsychNology Journal, 4(3), 245-265.

Sakaluk, J. K., \& Short, S. D. (2017). A Methodological Review of Exploratory Factor Analysis in Sexuality Research: Used Practices, Best Practices, and Data Analysis Resources. Journal of Sex Research, 54(1), 1 9. doi:10.1080/00224499.2015.1137538

Salovey, P., \& Grewal, D. (2005). The science of emotional intelligence. In.

Scheier, M. F., \& Carver, C. S. (1993). On the Power of Positive Thinking: The Benefits of Being Optimistic. Current Directions in Psychological Science. doi:10.1111/1467-8721.ep10770572

Schreiber, J. B., Nora, A., Stage, F. K., Barlow, E. A., Schreiber, J. B., Nora, A., . . Schreiber, J. B. (2013). Reporting Structural Equation Modeling and Confirmatory Factor Analysis Results: A Review. 0671(June), 1-15. doi:10.3200/JOER.99.6.323-338

Schutte, N. S., Malouff, J. M., Hall, L. E., Haggerty, D. J., Cooper, J. T., Golden, C. J., \& Dornheim, L. (1998). Development and validation of a measure of emotional intelligence. Personality and Individual Differences, 25(2), 167-177. doi:10.1016/S0191-8869(98)00001-4

Shaffer, J. (2002). Multiple Hypothesis Testing. Annual Review of Psychology. doi:10.1146/annurev.psych.46.1.561

Shmueli, G. (2009). To Explain or To Predict? Retrieved from

Skourdi, S., Rahimi, A., \& Bagheri, M. S. (2014). The Relationship between Emotional Intelligence, and Vocabulary Knowledge among Iranian EFL Learners. Procedia - Social and Behavioral Sciences. doi:10.1016/j.sbspro.2014.03.607

Sliter, M., \& Yuan, Z. (2015). Workplace Stress. In.

Smith, K. T. (2010). Work-life balance perspectives of marketing professionals in generation y. Services Marketing Quarterly. doi:10.1080/15332969.2010.510724

Steers, R. M., Nardon, L., Sanchez-Runde, C. J., Steers, R. M., Nardon, L., \& Sanchez-Runde, C. J. (2013). Managing a global workforce. 
Stringer, C., Didham, J., \& Theivananthampillai, P. (2011). Motivation, pay satisfaction, and job satisfaction of front-line employees. Qualitative Research in Accounting and Management. doi:10.1108/11766091111137564

Sturges, J., \& Guest, D. (2004). Work / life balance early in the career. Human Resource Management Journal.

Suhr, D. D., \& Ph, D. (1999). Exploratory or Confirmatory Factor Analysis ? Statistics and Data Analysis, 1-17. doi:10.1002/da.20406

Sullivan, T. A. (2014). Greedy institutions, overwork, and work-life balance. Sociological Inquiry. doi:10.1111/soin.12029

Sy, T., Tram, S., \& O'Hara, L. A. (2006). Relation of employee and manager emotional intelligence to job satisfaction and performance. Journal of Vocational Behavior. doi:10.1016/j.jvb.2005.10.003

Symonds, M. L., \& Russell, W. (2018). Intrinsic and Extrinsic Motivation of Small College Sports Officials. Journal of Sport Behavior.

Tabachnick, B. G., \& Fidell, L. S. (2012). Using multivariate statistics.

Taherdoost, H., Shamsul, S., \& Jalaliyoon, N. (2014). Exploratory factor analysis: Concepts and theory. Advances in Applied and Pure Mathematics, 375-382. doi:10.1017/CBO9781107415324.004

Taşdelen-Karçkay, A., \& Bakalım, O. (2017). The mediating effect of work-life balance on the relationship between work-family conflict and life satisfaction. Australian Journal of Career Development, 26(1), 3-13. doi:10.1177/1038416216682954

Tobias, S., \& Carlson, J. E. (1969). Brief report: Bartlett's test of sphericity and chance findings in factor analysis. Multivariate Behavioral Research. doi:10.1207/s15327906mbr0403_8

Tomasello, M., Carpenter, M., Call, J., Behne, T., \& Moll, H. (2005). Understanding and sharing intentions: The origins of cultural cognition. Behavioral and Brain Sciences. doi:10.1017/S0140525X05000129

Tremblay, M. a., Blanchard, C. M., Taylor, S., Pelletier, L. G., \& Villeneuve, M. (2009). Work Extrinsic and Intrinsic Motivation scale: its value for organizational psychology research. Canadian Journal of Behavioural Science, 41(4), 213-226. doi:10.1037/a0015167

Vealey, R. S., Chase, M. A., Block, C., \& Cooley, R. (2018). Confidence. In.

Vischer, J. C. (2007). The effects of the physical environment on job performance: Towards a theoretical model of workspace stress. In.

Vuga, J., \& Juvan, J. (2013). Work-family conflict between two greedy institutions - the family and the military. Current Sociology. doi:10.1177/0011392113498881

Whiteside, D. (1993). Training and development. Glass Technology.

Widhiarso, W., \& Psikologi, F. (2009). Praktek Model Persamaan Struktural (SEM) Melalui Program Amos. Wabyu Widhiarso | Pelatihan Analisis SEM Melalui AMOS Fakultas Psikologi UGM. 
Wilcox, R. R. (2012). Introduction to Robust Estimation and Hypothesis Testing.

Wolf, E. J., Harrington, K. M., Clark, S. L., \& Miller, M. W. (2013). Sample Size Requirements for Structural Equation Models: An Evaluation of Power, Bias, and Solution Propriety. Educational and Psychological Measurement. doi:10.1177/0013164413495237

Wright, P. M., \& McMahan, G. C. (1992). Theoretical Perspectives for Strategic Human Resource Management. Journal of Management. doi:10.1177/014920639201800205

Wuensch, K. L. (2015). An Introduction to Path Analysis. Multiple Linear Regression Viempoints. 